ROCZNIKI KULTUROZNAWCZE

Tom/Vol. XII, numer/number $2-2021$

DOI: http://doi.org/10.18290/rkult21122-5

ANDRIANNA ROMA

\title{
MYTHOLOGICAL COMPONENTS IN ROMAN PAGANISM TRADITION
}

\section{INTRODUCTION}

The Age of Antiquity unveils the unique epoch of ancient Rome. The greatness of the Eternal City is impressive and begs the question: How did a small Latin settlement - located at the intersection of trade routes of Etruscans and Hellenes - conquer half of the world and become one the most successful civilizations ever? The key lies in mentifacts - the key features of Roman uniqueness that are clearly represented in culture, religion, and mythology whose significance for the history of Rome and life of Romans cannot be denied.

The relevance of the research is supported by several reasons. First, the Roman mythology, essentially influenced by other nations, is insufficiently analyzed in terms of its authenticity. Second, the religious component of ancient Rome often passes unnoticed despite the great amount of scientific literature dedicated to its history and culture. Comprehensive innovative studies of ancient Rome were made by representatives of different countries and cultures: Gaston Boissier, Jean Bayeux, Georges Dumezil, John Scheid (France), Georg Wissova, Kurt Latte, Jörg RÜPKE (Germany), Robert M. Grant, Mary Beard (England), Gary Forsythe, Craig Champion, Hendrik Wagenvoort (Denmark), Liubomyr Khomin, Oleksandr Galamaga (Ukraine), Alexander Nemirovsky, Andrey Smorchkov, Olga Sidorovich (Russia), Elena Steierman, and Sergei Tokarev (USSR). An important contribution to the development of this issue is the work of the Polish historian Tadeusz Zielinski. Moreover, ancient Rome was an essential part of antiquity that became the

ANDRIANNA ROMA - Graduate student at the Taras Shevchenko National University of Kyiv; e-mail: andriannaroma13@gmail.com; ORCID: https://orcid.org/0000-0001-8570-6093. 
foundation of current Western civilization, whose values underlie the universal axiological paradigm, so that contemplation of these issues permits a deep understanding of culture in which we live.

Limited sources of Roman mythology complicate its study as they belong to a later stage of development of the Roman society - from $1 \mathrm{BC}$ to $4 \mathrm{AD}$. This period represents a more developed religious complex which was significantly influenced by the peoples conquered by Rome; it absorbed their practices and cults, assimilating their deities. The fact of foreign impact challenges the authenticity of Roman culture, especially mythology, but while the history of the Roman religion underwent different metamorphoses, it was able to preserve its independence and own identity.

\section{THE ROMAN RELIGION AND MENTALITY}

Religion is a complicated and multilevel phenomenon, regardless of its temporal, cultural, and geographical boundaries. In this article we defend its authenticity, highlighting the mythological components of Roman paganism, and assume that the mythology of the peoples of the Apennine Peninsula became a favorable background for the formation of Roman religion with all its key features - ritualism, politicization, over-detailing, formalism, and practicality.

In Roman religion, the historical component prevails over the mythological one, however mythology still is the core of the cultural code of any nation, as long as it encodes thinking, describes the way of life, and formulates mental constructs. Although it is difficult to say whether the Romans had their own mythological structure or it was the result of some cultural strata, the Roman paganism tradition clearly shows its mythological components. For example, the tendency to over-detail rituals is usually explained by the professional deformation of priests, who were the products of Roman legal and bureaucratic culture. However, we can assume another explanation, which tends to the heart of the cultural code - myth, which historically is the first type of social consciousness. Myth classifies inventories, organizes, differentiates, and deeply influences people's outlooks. If we look at old spells (centuries later they will transform into a more sophisticated form of religious worship, i.e., prayer), we will notice that they are long and detailed.

The large number of invocations follows from the lack or inability of abstract thinking. Primitive man, who begs a deity for protection or healing, 
does not ask to get rid of a particular trouble, but he lists each individual case where protection is sought. This moment is deeply rooted in the consciousness of archaic man and, in the case of the Romans, persists in the later stages of the development of religious beliefs. A similar point can be traced in the specific belief of the early stages of Roman religion, that is, numina.

Numina is an idea of various useful and harmful forces that later give rise to an infinite number of deities in Roman pantheon. The idea of numina explicates the diffuse thinking of ancient people when everything around becomes spiritual and personified. Any element of nature could be regarded as a divine act and given a name and a cult. Thus, the Romans have

a deity forcing the baby to utter the first sound (Vaticanus) or the first word (Fabulinus), or to lie quietly in the cradle (Cuba). The goddess Educa teaches a newborn to eat, Polina prompts to drink, Abeona and Adeona look after a child when it leaves the house, Iterduca and Domiduca accompany it on the way home. There is an explanation of mythological semanticization (function of the name), when the activity of the deity is encoded in his name: Iterduca — from Latin Iter (path, course, movement), Domiduca - from domus (house), Fabulinus - from fabulari (speak, talk).

Even though the ancient Romans clearly knew which deity was responsible for a particular act, they had no idea what the deity looked like. ${ }^{1}$ The Roman pantheon became anthropomorphic due to acquaintance with the mythological ideas of Greece. The branching of the Roman deities compared with structured pantheon of Greek gods and their developed religious complex positions Roman religion as somewhat primitive, but such view is not objective. The idea of the numina as a huge number of individual deities is most likely a distortion of the reality of that time. The "deities of moments," which the numina were in essence, in fact are manifestations of the functions of deities, their attributes, force and will. Distorted ideas of gods appear, first, because of the limited sources of the more archaic period, and secondly, because of the Indigitamenta - lists of deities, kept by pontiffs. Roman priests were also officials or lawyers, hence the tendency to detail any phenomenon, especially any religious cult that was an important part of Roman social and political life.

In the ancient Roman society religion actualizes at two levels: official and popular. At the official level, it manifests itself as a high religion (the doctrine, axiological paradigm, cult standards, and institutionalization); at the po-

\footnotetext{
${ }^{1}$ Gaston Bossier, Rimskaya religiya ot Avgusta do Antoninov, trans. Mariya Korsak (Moscow: K. T. Soldatenkov, 1878), 14.
} 
pular level, religion appears as a folk tradition (beliefs and rites). The Roman religion functioned in various spheres of life: in the public sphere (sacra publica) it was a social and political regulator that defined favorable and unfavorable days for meetings, made calendars, formalized the institution of priesthood, established rules and norms of rites, and decided which gods deserved honor and sacrifices. In everyday life (sacra privata) religion settled norms for private life, gave a hint how to honor household lares, which of various deities could help with childbirth, fruitful harvest, or good health. In the personal sphere, religion was always a link between the human and divine - the world of human dreams and the supernatural world.

\section{THE ROMAN CALENDAR}

The discovery of mythological components becomes especially interesting in the study of the history of the Roman calendar. Calendars are present almost in every culture. They help in social regulation, correlating with sacred time and sacred space. Calendarium literally means "register of debts" and refers to the first day of month (calendae, the calends) when loans were given, and interest was paid off. Accordingly, Roman calendar had nothing with abstract chronology. As Jörg Rupke says: "Calendar is a document, a graphic, a text with particular look and particular function." 2 According to John Scheid, the Romans had a natural calendar (agrarian, which regulated agricultural work) and civil (organized by magistrates, which determined the conduct of socio-political, trade, economic, legal, and military activities). ${ }^{3}$ Roman civil calendars, called Fasti, were specific tablets or figures with appropriate symbols that indicated which day was auspicious for domestic things and which should be dedicated to the worship of gods (sometimes the names of the gods appeared in the Fasti, meaning that this day was one of the main public holidays in honor a deity). Priests compiled the calendar, but any introduction was determined by Roman law.

The life of the ancient Romans was regulated to the smallest details, not even the days were an exception as they were all divided into three groups: dies festus (holidays in which feasts were held, prayers and sacrifices were done), dies profestus (non-holiday days set aside for daily affairs, personal or

\footnotetext{
${ }^{2}$ John Schied, Rimskaya religiya, trans. Olga Smirnova (Moscow: Novoe Izdatelstvo, 2006), 363.
} 
socio-political), and dies intercisi (separate days in which certain time were set aside to worship the gods, and other one to solve public affairs).

At the beginning the calendar was lunar and every first the calends coincided with the appearance of a new moon. Initially, the Roman calendar had 10 months, which were approved by the legendary king Numa Pompilius: Martius, Aprilis, Majus, Junius, Quintilis (5th), Sextilis (6th), September (7th), October (8th), November (9th), and December (10th).

Before the reform of Julius Caesar (46 BC), who named a month after himself, the reform would be completed by Augustus, who carved his own name in the name of the month Augustes. Two first winter months did not exist as they were "dead" for agriculture. As the phenomenon of calendar is causally related to agricultural cycles, the need of extra months disappears. Thanks to Caesar's reform Romans got 12 months, which were either etymologically tied to the names of the deities and emperors or were numerals from the previous system.

The first month Januarius was dedicated to Janus, the god of doors, borders, and beginnings of any kind. Janus has two faces, looking in opposite directions, symbolizing mythological binary opposites: friend or foe, right or left, front or back. Janus keeps an eye on the territory of Rome and protects city boundaries, literally watching who wants to enter the door, the gate, therefore, symbolically, he is the one who becomes the originator of the new year, being on the threshold of the past and future.

This month celebrated Kalendae Januariae, which was the beginning of the new year. On this holiday the ancient Romans exchanged symbolic gifts sweet fruits and copper coins - to make the year sweet and prosperous. In addition, to ensure productivity for the whole year, work had to be done on this day work impeccably. Probably elections to the senate on this day in the Late Republic was for the same reason.

The etymology of the second month, February, is related to Latin februa denoting purifying branches. It can be assumed that at this time the rites of purification were performed that were necessary before the beginning of the new economic cycle. Among the other significant holidays, Lupercalia, Feralia and Charistia were celebrated in that month. Lupercalia (after the 15th) was one of the oldest Roman holidays, associated with purification rites and the cult of fertility. The name of the holiday demonstrates the connection with Lupercus (from lupus meaning 'wolf') the patron of cattle and shepherds, later identified as Faunus - the deity of fertility, animals, meadows, and fields. To control the celebration of these holidays in Rome, there was even a separate 
priestly collegia. Feralia (19th-21st) were the prototype of the funeral father's days. Gifts (food and flowers) were brought to the dead who rested in their tombs, both to honor them and to seek their help. Charistia (22nd) closed the cycle of paternal days (dies parentales) and were dedicated to the joy of life. Only family members were present at the holiday, during which all the family troubles were forgotten.

Martus was a month dedicated to Mars (Mart), the god of war, who initially was an agricultural deity, patron of fertility, vegetation, and wildlife. The identification of Mars with the god of war is probably related to the sociopolitical transformations of the Roman society: if the Romans originally led a sedentary lifestyle, the main task was to appease the deity, who could send or avert failure from the harvest. Later Rome began a policy of conquest and the deity himself became the personification of war.

At the beginning of this month was a maternal holiday, the Matronalia, established in honor of Juno (female goddess). Husbands gave their wives gifts, and the wives themselves treated the servants. On the 15th day they celebrated a holiday in honor of Anna Perenna (from the Latin annus denoting 'year' and perennis for 'eternal' or 'continual') - the goddess of the new year, which before the reform of Caesar began in March. The name of the goddess reflects the cyclical perception of time. Banquets on this holiday took place in the sacred grove on the Tiber. It was followed by the Quinquatrus, the holiday of Minerva, the goddess of arts and crafts, the patroness of all who studied (under the influence of the Hellenic world she became the goddess of wisdom and identified as Athena).

The etymology of Aprilis is still unclear, there are only assumptions of its connection with the name of the Greek goddess of beauty and love Aphrodite. Since the Latin name of April Aprilis correlates with Greek Aphro (an abbreviation of 'Aphrodite'), it is possible that the month is dedicated to Aphrodite, who was imagined as the "goddess of fertility, eternal spring and life."

Between the 4th and the 10th was Megalesia - the feast to honor the Great Mother (Megale Mater), most likely a prototype of the goddess of fertility, the earth. The following holiday was Fordicidia (15th) in honor of Tellus (an agrarian deity). 30 pregnant cows were sacrificed on this day to ensure fertility for the next year. The ceremony was led by Vestals, who removed the calves from intestines, burned them, and kept the ashes until the next holiday Parilia (21st) in honor of Pales - the goddess of cattle, patroness of shep-

\footnotetext{
${ }^{4}$ Bossien, Rimskaya religiya ot Avgusta, 110.
} 
herds. Later this day was transformed into Natalis Urbis - the day of the founding of Rome. From the 28th a celebration of Ludi Floralis went on for 6 days, dedicated to Flora (the goddess of flowers, gardens, flowering ears). The floral games connected with the agricultural cult, the sacred marriage of heaven and earth (fertilization of the earth) in archaic societies was symbolically reproduced by people, therefore, agricultural holidays quite often contained sexual elements.

Majus - the month of the "nursing mother" Maya (Maia) - the patroness of nature and fertile land. In this month (on the 9th, 11th, and 13th) were Lemuralia (Lemuralii) - the days of the dead. It was believed that in those days the spirits of the dead (lemurs and laurels) roamed the city. On Lemuralii temples were closed and weddings were not held. Homeowners walked around the house and threw black beans at the spirits to protect their homes from unwanted guests. Then would wash with water and beat in copper basins to force the spirits to leave.

Juni is associated with Juno, the goddess of marriage, motherhood, women, female fertility, patroness of fertility. On the 11th, there was the feast of Matralia in honor of Mater Matuta - the patroness of married women, the goddess of fertility and morning (she probably became the prototype of Aurora, the goddess of the morning star), to whom matrons brought cakes on that day. On the 24th, Fars Fortuna was celebrated to honor Fortuna, the goddess of fate, happiness, and fortune, who was originally identified as the goddess of harvest, motherhood, and womanhood.

Julius (formerly Quintilis - the 5th), as already mentioned, is named after Julius Caesar. On the 7th day, there was a celebration of Nonae Carpotinaethe feast of slaves in honor of Philotida (according to a legend, a slave who helped the Romans to win during the war of the Roman Kingdom), dancing under a fig tree.

Augustes (formerly Sextilis - the 6th) is the month of Augustus. On the 13th, the slaves celebrated a holiday in honor of Diana, the goddess of vegetation, the personification of the moon. Vinalia (the 19th) was the holiday of winemaking, the beginning of the grape. On the 21 st, Consualia was celebrated in honor of the grain god Consus (later the functions of Consus underwent transformations, he became the god of good advice. He was followed on the 23rd by Vulcanaliae, a holiday in honor of Vulcanus, the god of fire, purifying and destructive. On this day, bonfires were lit, and animals were sacrificed to protect against fires. 
In autumn there were few holidays. In September (the 7th) no fests were celebrated, but games called Ludi Romani, were held. In October (the 8th) there was a celebration of Fontinalia - a holiday of water source. Wells were decorated with flowers; wreaths were thrown into the water and wine was poured. In November, and also in September, there were no important holidays other than games (Ludi Plebeii).

In December (the 10th) there was a great celebration of Saturnalia to honor Saturn - the god of agriculture, who, as legends have it, ate his children. Saturnalia were celebrated on the 17th and 23rd, during the winter solstice. If we draw a parallel with the Greek Kronos, whose name represents time, Saturn could also be identified with time, which mercilessly erases everything from the face of the earth. In the last month, no agricultural work was done, the world was symbolically dying (even though the warm climate of the Apennine Peninsula does not fully reflect the "dying" of the world that occurs in winter) to be revived (according to the astronomical cycle, when, after the winter solstice, each day becomes longer than the previous one).

\section{CONCLUSION}

Considering even a small fragment of the Roman paganism tradition, the mythological components that reflected the worldview of ancient Romans can be seen. Despite the rational and pragmatic mentality of the Romans, the juristic nature of their thinking should not be overestimated. Religion as an area of human fears and emotions is the least subject to rational systematization. Romans are mostly portrayed as powerful warriors, invaders, victors, gladiators, persecutors of Christians, skilled officials and legislators, and very rarely as ordinary people with quite archaic thinking and mythologized worldviews - simply as humans.

\section{BIBLIOGRAPHY}

Bossier, Gaston. Rimskaya religiya ot Avgusta do Antoninov. Translated by Mariya Korsak. Moscow: K. T. Soldatenkov, 1878 | Буасье, Гастон. Римская религия от Августа до Антонинов. Пер. Мария Корсак. Москва: Издание К. Т. Солдатенкова, 1878.

Khomyn, Lyubomyr. "Relihiya Drevnoho Rymu.” Volynskyi Blahovisnyk, no. 2 (2014): 73-84 | Хомин, Любомир. «Релігія Древнього Риму». Волинський благовісник, № 2 (2014): c. 73-84. 
Forsythe, Gary. Time in Roman Religion. One Thousand Years of Religious of Religious History. New York: Taylor \& Francis, 2012.

RÜPKE, Jörg. Religion in Republican Rome: Rationalization and Ritual Change. Philadelphia: University of Pennsylvania Press, 2012.

RÜPKE, Jörg. Religion of the Romans. Translated and edited by Richard Gordon. Cambridge: Polity Press, 2007.

RÜPKE, Jörg. Religious Deviance in the Roman World: Superstition or Individuality. Cambridge: CUP, 2016.

RÜPKE, Jörg. On Roman Religion: Lived Religion and the Individual in Ancient Rome. London: Cornell University Press, 2016.

RÜPKE, Jörg. Pantheon: A New History of Roman Religion. Translated by David Richardson. Princeton: Princeton University Press, 2018.

RÜPKE, Jörg. The Roman Calendar from Numa to Constantine: Time, History, and the Fasti. Translated by David Richardson. Boston: Wiley-Blackwell, 2011.

Schied, John. Rimskaya religiya. Translated by Olga Smirnova. Moscow: Novoe Izdatelstvo, 2006 | Шайд, Джон. Религия римлян. Пер. Ольга Смирнова. Москва: Новое издательство, 2006.

SmorchKov, Andrey. Religion and government in Roman Empire. Moscow: RGHU, 2012

Сморчков, Андрей. Религия и власть в Римской республике. Москва: РГХУ, 2012.

\section{MYTHOLOGICAL COMPONENTS IN ROMAN PAGANISM TRADITION}

\section{Summary}

The culture of ancient Rome is impressive with its uniqueness, so scholars have always been interested in it. In ancient societies religious component always plays a great role, so studying it becomes key in understanding the depth of human feelings. The ancient perception of the world is clearly represented in mythology, the first type of human consciousness, whose reflections manifest itself in all the following stages of human development. The article seeks to identify the mythological components in Roman paganism tradition that facilitates deep understanding of the religion of ancient Rome. At the same time, the cornerstone of the study is the relationship between the religious and the human - what role in the process of social and cultural transformations the religious component played, how deeply mythological components intertwined with religious doctrine, what was the nature of the relationship of the Romans with their gods, and how the features of mentality transformed universal human aspirations as seen by the ancient Romans. A comprehensive analysis of this issue opens up further prospects for research, which can be considered a broader layer of the culture of ancient Rome.

Keywords: Roman religion; Roman deities; mythology; Roman calendar; sacra privata; sacra publica; rites. 
ELEMENTY MITOLOGICZNE W TRADYCJI POGAŃSTWA RZYMSKIEGO

\section{Streszczenie}

Kultura starożytnego Rzymu jest w urzekający sposób wyjątkowa, dlatego uczeni od zawsze się nią interesowali. W starożytnych społeczeństwach komponent religijny zawsze odgrywał wielką rolę, dlatego jego badanie staje się kluczem do zrozumienia głębi ludzkich uczuć. Starożytna percepcja świata jest wyraźnie widoczna w mitologii, która jest przejawem ludzkiej świadomości, a której odbicie przejawia się we wszystkich kolejnych etapach rozwoju człowieka. Artykuł ma na celu wskazanie komponentów mitologicznych w tradycji pogaństwa rzymskiego ułatwiających dogłębne zrozumienie religii starożytnego Rzymu. Jednocześnie fundamentem badań jest relacja między tym, co religijne, a tym, co ludzkie - jaką rolę w procesie przemian społecznych i kulturowych odgrywał komponent religijny, jak głęboko komponenty mitologiczne splatały się z doktryną religijną, jaki był charakter relacji Rzymian $\mathrm{z}$ ich bogami, jak według starożytnych Rzymian cechy mentalności wpływały na uniwersalne dążenia człowieka. Wszechstronna analiza tego zagadnienia otwiera dalsze perspektywy badawcze, które można uznać za szerszą warstwę kultury starożytnego Rzymu.

Słowa kluczowe: religia rzymska; bóstwa rzymskie; mitologia; kalendarz rzymski; sacra privata; sacra publica; obrzędy. 